\title{
Effect of propionobacterium and E.Coli lipopolysaccharide (inmunair 17.5) immunomodulator on response of rabbits to RHDV vaccine
}

\author{
M. A. Abdel-Khalek ${ }^{1}$, O. A. Hady ${ }^{2}$ \\ ${ }^{1}$ Veterinary Serum and Vaccine Research Institute and ${ }^{2}$ National Organization for Drug Control and \\ Research,Cairo, Egypt.
}

\begin{abstract}
The present study was conducted to study the immunomodulatory effect of combined of extract of propionobacterium and E.coli lipopolysaccharide (inmunair 17.5) to enhance the immune response of rabbits to rabbit haemorrhagic disease virus (RHDV) vaccine. Forty New Zealand rabbits aged 2 months with average weight 1.5-2 kgs were divided into 4 equal groups. Group (1) was vaccinated with RHDV vaccine and the immunomodulator, group (2) was only vaccinated with RHDV vaccine, group (3) was received the immunomodulator only and the last group was kept as non-vaccinated, no-treated control. The results revealed that three days oral administration of the immunomodulator under test at time of RHDV vaccination had an improving effect on both humoral and cell mediated immune response of rabbits to RHDV vaccine. Results obtained by challenge test come in harmony with serological test.
\end{abstract}

Rabbit haemorrhagic disease (RHD) is a contagious highly fatal disease of rabbits, characterized by a high morbidity and mortality (Capucci et al., 1997).

The common features of the disease are anorexia, dyspnoea, abdominal respiration, abortion in pregnant does, bloody nasal discharge, organs excitement and convulsion followed by rapid collapse and death (CAP, 1989). The characteristic pathological lesions were haemorrhages in respiratory system, liver, spleen, cardiac muscles and occasionally in the kidney (Parra and Prieto, 1990). Due to viral etiology of the disease, vaccination is considered the efficient method to eradicate the disease (Daoud et al., 1998). Rabbits may be exposed to immunosuppressive factors, such as concomitant infection with myxomatosis, pasteurellosis or coccidiosis (Gergis et al., 1993) as well as physiological factors.

Another reason for vaccination failure under field conditions could be due to management errors, bad hygiene and uncontrolled environment.

Immunomodulators can play a very important role in enhancing the response of the immune system to a particular antigenic stimuli as brought by the process of vaccination (Gatenby, 1998), or by restoring the immunodepressive effect of various factors (Chedid et al., 1986).
The objective of this work was studying the possible immunopotentiating effect of a biological substance prepared from inactivated cells of Propionobacterium acnes and lipopolysaccharide from Escherichia coli on both the humoral and cellular immune response of rabbits vaccinated with the inactivated RHD vaccine.

\section{Material and methods}

Exprimental animals. Forty white New zealand rabbits (aged 2 months with average weight 1.5-2 kgs) were purchased from private rabbiteries which had neither a history of RHDV infection nor vaccination. They were seronegative for RHD virus antibodies.

Virus. Virulent RHDV (local isolate) identified against reference immune serum by Prof. Dr. H.M.Hafez, Free Univ., Berlin, Germany during M.V.Sc. thesis (Poultry \& Rabbit Diseases) by (Salman, 1999). It was sequenced and submitted to GenBank with accession No. EF488823, (Salman, 2007). It had a titre of $2048 \mathrm{HA}$ unit $/ \mathrm{ml}$ and $\mathrm{LD}_{50}$ of $10^{6.5} / \mathrm{ml}$.

The commercial Immunomodulator (inmunair 17.5). Each $1 \mathrm{ml}$ of the immunostimulant (Laboratorios Calier, S.A. Spain) contained inactivated propionobacterium acnes cells $(0.17$ $\mathrm{mg}$ ) and lipopolysaccharide from apathogenic E.coli cell wall $(0.05 \mathrm{mg})$. Administration was in the drinking water at the range of $1 \mathrm{ml} / 10 \mathrm{Kg}$ 
body weight, every 24 hours during 3 consecutive days.

Preparation of RHDV vaccine. The vaccine was prepared according to (Arguello Villares, 1991; Salman, 1999), where livers of dead experimentally infected rabbits with RHDV, were homogenized in phosphate buffered saline $(\mathrm{pH}$ 7.2) and was centrifuged at $3000 \mathrm{rpm}$ (15 minutes) at $4{ }^{\circ} \mathrm{C}$. The supernatant was collected and inactivated with $0.4 \%$ formalin at $37^{\circ} \mathrm{C} / 48$ hours. After safety examination, the vaccine was ready for use in experimental rabbits. The suspension was adjuvenated with aluminum hydroxide gel (Honel, UK) at a final concentration of $20 \%$. The recommended vaccine dose $(0.5 \mathrm{ml} /$ animal $)$ contained protective virus titre (1024 HA unit), was inoculated S/C as stated by (Smid et al., 1991).

Vaccination. Rabbits were divided into 4 groups (10 rabbits/group), group (1) was vaccinated $\mathrm{S} / \mathrm{C}$ with RHDV vaccine $(0.5 \mathrm{ml} /$ animal $)$ in combination with inmunair 17.5 in drinking water. Group (2) was only vaccinated with RHDV vaccine .Group (3) was received inmunair 17.5 only in drinking water. The last group was kept as non-treatd-non-vaccinated controls. Blood samples were collected at regular intervals for evaluation of immune response for 24 weeks.

Evaluation of humoral immune response.

Haemagglutination inhibition test (HI). It was performed according to the method previously described by (Pu et al., 1985).

ELISA test. The test was carried out according to (Smid et al., 1991).

Evaluation of the cell mediated immune response.

Lymphocytes blastogenesis assay. It was carried out by tetrazolium calorimetric assay according to (Mosmann, 1983) and the results were expressed as delta optical density $(\Delta \mathrm{OD})$.

Macrophage activity test. It was performed by the method of (Barry et al., 1988) and modified by (El-Enbawy, 1990).

Phagocytic \% =

$\frac{\text { Noof phagocytic cells whichingest candida }}{\text { total No of phagocytes }} \times 100$

Phagocytic index. It was done according to Richardson and Smith (1981).

Phagocytic index $=$

Total No of phagocytes which ingest morethan two candida Total No of phagocytes whichingest candida

Potency test. All rabbits were challenged with 100 LD50 of virulent fully characterized RHDV(Giza 1997) after three weeks post vaccination, and observed for signs of RHDV for one week after challenge infection (Salman, 2007).

\section{Results and Discussion}

Interest in the topics of immunomodulation has expanded rapidly in recent years, with the realization of its potential in human and veterinary medicine (Barltt and Kreider, 1981). Recently, non-specific immunostimulant are gaining increasing attention in recent years to counteract the effect OF environmental immunosuppressive factors and help the animal in its struggle against disease causing agents and potentiating of its immune response to applied vaccines.

This work was directed to demonstrate the possible promoting effects of the incorporated immunomodulator prepared from extracts of propionobacterium and lipopolysccharides of E.coli on the immunogenic properties of RHDV vaccine given to rabbits.

Humoral immune responses against RHD virus was estimated by $\mathrm{HI}$ and ELISA test as shown in tables (1 and 2), respectively. The results revealed that the antibody titers in rabbits received inmunair 17.5 immunomodulator with RHDV vaccine (G1) began earlier and higher than those vaccinated only $(\mathrm{G} 2)$ and non-treated.

These results accord with those of Tizzard (2000) who stated that propionobacterium acnes, posses adjuvant activity which enhance antibody formation against viral infection.

Concerning the cellular immune response, results of lymphocyte blastogenesis as represented in table (3) revealed that a maximum response of $\mathrm{T}$ cells expressed as $\Delta \mathrm{OD}$ in animals of group 1 ( vaccinated and treated with the immunomodulator ) in comparison with those vaccinated with RHD vaccine only $(\mathrm{G} 2)$.

More confirmation of cellular immune response was also achieved using macrophage activity test (tables 4 and 5) as expressed by phagocyic index and phagocytic percentage respectively were running parallel to the former test.

The recorded improvement in the measured immune parameters can be attributed to the LPS contains of the used immunomodulator as mentioned before by (Johnson 1975; Waksman, 1979) has recording increase the phagocytic activity and the production of inflammatory cells, they also stimulate the production of interferon and activate complement.

Schultze and Goodman (1979) stated that the immunomodulation effect is manifested by the 
Table (1): Mean haemagglutination inhibition titers $(\log 2)$ induced by RHDV vaccine.

\begin{tabular}{|c|c|c|c|c|c|c|c|c|c|}
\hline \multirow{2}{*}{ Group } & \multicolumn{2}{|c|}{ Treatment } & \multicolumn{7}{|c|}{ Weeks post vaccination } \\
\hline & Vaccine & I.M.* & 2 & 4 & 8 & 12 & 16 & 20 & 24 \\
\hline G 1 & + & + & 8.5 & 8.8 & 8.7 & 9.6 & 9.7 & 9.2 & 7.9 \\
\hline G 2 & + & - & 7.6 & 8.7 & 8.8 & 8.3 & 8 & 7.8 & 6.3 \\
\hline G 3 & - & + & 0 & 0 & 0 & 0 & 0 & 0 & 0 \\
\hline G 4 & - & - & 0 & 0 & 0 & 0 & 0 & 0 & 0 \\
\hline
\end{tabular}

*I. M. Immunodulator.

Table (2): ELISA mean optical density in sera of rabbits vaccinated with RHDV vaccine (mean absorbance values).

\begin{tabular}{llllllll}
\hline \multirow{2}{*}{ Group } & \multicolumn{7}{c}{ Weeks post vaccination } \\
\cline { 2 - 8 } & $\mathbf{2}$ & $\mathbf{4}$ & $\mathbf{8}$ & $\mathbf{1 2}$ & $\mathbf{1 6}$ & $\mathbf{2 0}$ & $\mathbf{2 4}$ \\
\hline G 1 & 0.05 & 0.72 & 0.952 & 1.11 & 0.96 & 0.93 & 0.89 \\
G 2 & 0.5 & 0.71 & 0.89 & 0.80 & 0.76 & 0.73 & 0.70 \\
G 3 & 0.06 & 0.09 & 0.05 & 0.15 & 0.05 & 0.05 & 0.04 \\
G 4 & 0.058 & 0.49 & 0.05 & 0.05 & 0.05 & 0.06 & 0.06 \\
\hline
\end{tabular}

Table (3): Evaluation of cell mediated immune response by MTT of treated rabbits.

\begin{tabular}{lllll}
\hline \multirow{2}{*}{ Groups } & \multicolumn{4}{c}{ Days post vaccination } \\
\cline { 2 - 5 } & $\mathbf{4}$ & $\mathbf{1 1}$ & $\mathbf{1 8}$ & $\mathbf{2 5}$ \\
\hline G1 & 0.093 & 0.083 & 0.104 & 0.010 \\
G2 & 0.035 & 0.044 & 0.109 & 0.005 \\
G3 & 0.024 & 0.0285 & 0.010 & 0.001 \\
G4 & 0.004 & 0.012 & 0.011 & 0.010 \\
\hline
\end{tabular}

Table (4): Phagocytic activity of rabbits vaccinated by RHDV vaccine and treated with inmunair 17.5 expressed by phagocytic index.

\begin{tabular}{llll}
\hline \multirow{2}{*}{ Groups } & \multicolumn{3}{c}{ Weeks post vaccination } \\
\cline { 2 - 4 } & $\mathbf{1}$ & $\mathbf{2}$ & $\mathbf{3}$ \\
\hline G1 & 0.77 & 0.857 & 0.55 \\
G2 & 0.75 & 0.810 & 0.50 \\
G3 & 0.22 & 0.260 & 0.12 \\
G4 & 0.10 & 0.090 & 0.08 \\
\hline
\end{tabular}

Table (5): Phagocytic activity of rabbit vaccinated by RHDV vaccine and treated by inmunair 17.5 expressed by phagocytic percentages.

\begin{tabular}{llll}
\hline \multirow{2}{*}{ Groups } & \multicolumn{3}{c}{ Weeks post vaccination } \\
\cline { 2 - 4 } & $\mathbf{1}$ & $\mathbf{2}$ & $\mathbf{3}$ \\
\hline G1 & 74.20 & 77.7 & 70.00 \\
G2 & 70.00 & 72.72 & 69.20 \\
G3 & 25.60 & 15.57 & 9.400 \\
G4 & 11.11 & 10.50 & 10.00 \\
\hline
\end{tabular}

Table (6): Potency test of immunized rabbits challenged by $100 \mathrm{LD}_{50}$ RHDV.

\begin{tabular}{lllll}
\hline Group & No. of rabbits & Died/survived & $\begin{array}{l}\text { Total } \\
\text { number }\end{array}$ & Protection \% \\
\hline G1 & 10 & $0 / 10$ & 10 & $100 \%$ \\
G2 & 10 & $1 / 9$ & 9 & $90 \%$ \\
G3 & 10 & $8 / 2$ & 2 & $20 \%$ \\
G4 & 10 & 0 & 0 \\
\hline
\end{tabular}

synthesis and secretion of immunoglobulins enhancing the humoral immune response.

Propionibacterium acnes have been reported to stimulate non-specific resistance to viral infection (Carter and Wagner, 1984) activate both
$\mathrm{B}$ and $\mathrm{T}$ lymphocytes, as well as activate to macrophages (Frost and Lance, 1973).

Results of challenge test ( table 6) revealed that rabbits vaccinated with RHDV vaccine and treated with the immunomodulator ( $\mathrm{G} 1$ ) gave 
high protection (100\%) compared to $90 \%$ in rabbit received RHDV vaccine only (G 2 ) and $20 \%$ in treated group ( $\mathrm{G} 3$ ). The bioassay test against RHDV vaccine confirmed the above mentioned humoral and cell mediated immune response.

In conclusion, the orally administration of immunomodulator in combination with RHDV vaccine appear to show a tendency in putting off the pathogenisity of RHDV , and it can be of value in reducing the incidence of such viral infection if used under rabbiteries conditions in Egypt.

\section{References}

Arguello Villares,J.L. (1991): Viral haemorrhagic disease of rabbits, vaccination and immune response. Rev.Sci.Tech.Int.Epiz., 10(2): 471-480.

Barlett,G.L. and Kreider,J.W. (1981): Animal model for evaluating therapeutic potential of immunostimulants (ed) edited by Hersh et al., Reveis Press, N.Y., pp 1-3.

Barry,G.; John,R. and Elisson (1988): In vitro microbial activity of avian peritoneal macrophages. Avian Dis., 33: 177-181.

Capucci,L.; Nardin,A. and Ivazza,A. (1997): Seroconversion in an individual unit of rabbits infected with a non-pathogenic rabbit haemorrhagic disease-like virus from the United Kingdom. Vet. Rec. 140, 647-650.

Carter,G.R. and Wagner,E.C. (1984): Pasteurella multocida and Pasteurella haemolytica. Advance Vet.Sci., 11: 321-379.

Chedid,L.; Corel,C. and Audibert,F. (1986): Use of adjuvants, antigens and carrier in synthetic veterinary vaccines. In advances in carriers and adjuvants for veterinary biologics (ed), Iowa State University Press, pp. 52-54.

CPA (1989): Enfermedad haemorragica viral de los Conejos. Boltein extra CPA, commission, Mexico-Estado unidos para la prevencion de la fiebre aftosay otras Enfermedades Exoticas de los Animals, Mexico.

Daoud,A.M.; Khodier,M.H.; Abbas,A.M. and Ibrahim,S.I. (1998): Preparation of specific inactivated vaccine against rabbit haemorrhagic disease vrus. $4^{\text {th }}$ Scientific Veterinary Medical Conference, 26-28 Aug., 230234.
El-Enbawy,M.I. (1990): Some studies on Candida albicans. Ph.D.Thesis (microbiology), Fac.Vet.Med., Cairo University, Egypt.

Frost,P. and Lance,E.M. (1973): The relation of lymphocyte trapping to the mode of action of adjuvants. Ann. Report i Med. Chem., 14: 146-467.

Gatenby (1998): Encyclopedia of immunology. Acad.Press,N.Y., USA.

Gergis,S.M.; Wafaa,A.G.; S.M.Abo El-Saoud; A.H.Hassan; Samira,A.A. and Suzan,F.G. (1993): Immune response of rabbits to polyvalent pasteurella vaccines. Beni Suef Vet. Med. Res., 3(2): 86-93.

Johnson,A.G. (1975): Endotoxins as adjuvant. Cancer Res., 37:3990-3994.

Mosmann,T. (1983): Rapid calorimetric assay for cellular growth and cytotoxicity assays . J.Immunol.Methods, 65, 55. Parra,F. and Prieto,M. (1990): Purification and characterization of a calcivirus as the causative agent of a lethal haemorrhagic disease in rabbits. J.Virol., 64(8): 40134015.

Pu,B.Q.; Qian,N.J. and Cui,N.J. (1985): HA and HI tests for detection of antibody titer to so called haemorrhagic disease in commercial farms, efficacy of an inactivated vaccine. Vet.Microbiol., 26: 77-85.

Richardson,M.D. and Smith,H. (1981): Resistance of virulent and attenuated strains of Candida albicans to intracellular killing by human and mouse phagocytes. J.Infect.Dis., 144: 557-565.

Salman,E.G.A. (2007): Further studies on Haemorrhagic Viral Disease in rabbits in Egypt. Ph.D. Thesis, Fac.Vet. Med. Cairo Univ., Egypt.

Salman,E.G.A. (1999): Studies on Haemorrhagic Viral Disease in rabbits. M.D.Sc.Thesis, Fac. Vet. Med. Cairo Univ., Egypt.

Shultze,B.M. and Goodman,G.W. (1979): Endotoxins protein of B-cell mutagen and polyclonal activator lymphocytes. J.Exp.Med. 144: 821-844.

Smid,B.,Valicek; L.Rodak; I.Stepanek,J. and Jurak,E. (1991): Rabbit haemorrhagic disease: an investigation of some properties of the virus and evaluation of an inactivated vaccine. Vet. Microbiol. 26: 77-85.

Tizard,I.R. (2000): Veterinary immunology: An introduction. $6^{\text {th }}$ ed., W.B., Saunders Company, Pennsylvania, USA.

Waksman,B.H. (1979): Adjuvants and immuno-regulation by lymphoid cells. Immunopathology, 2: 5-33.

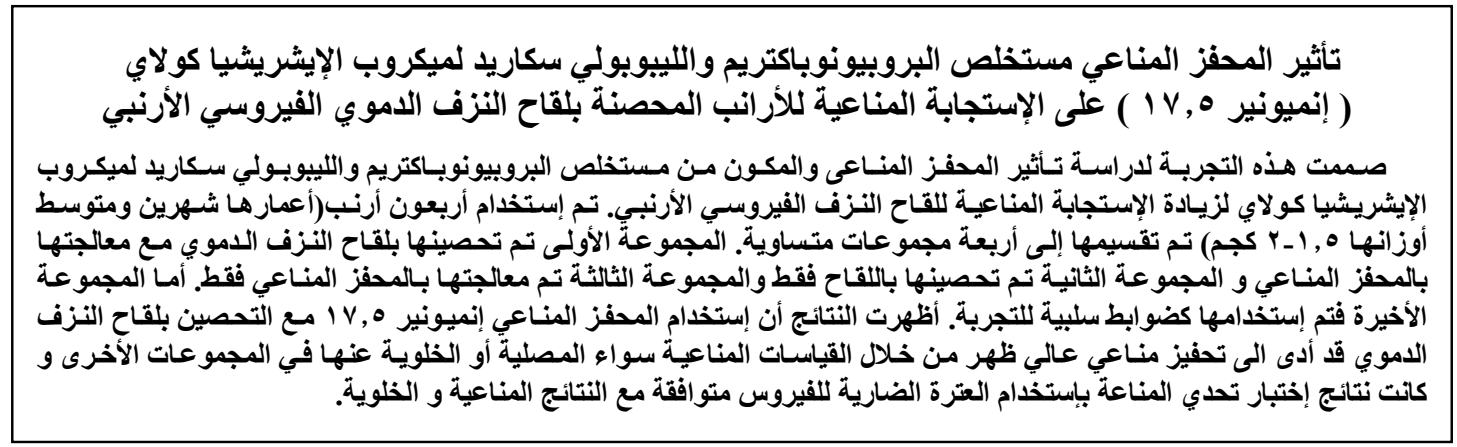


